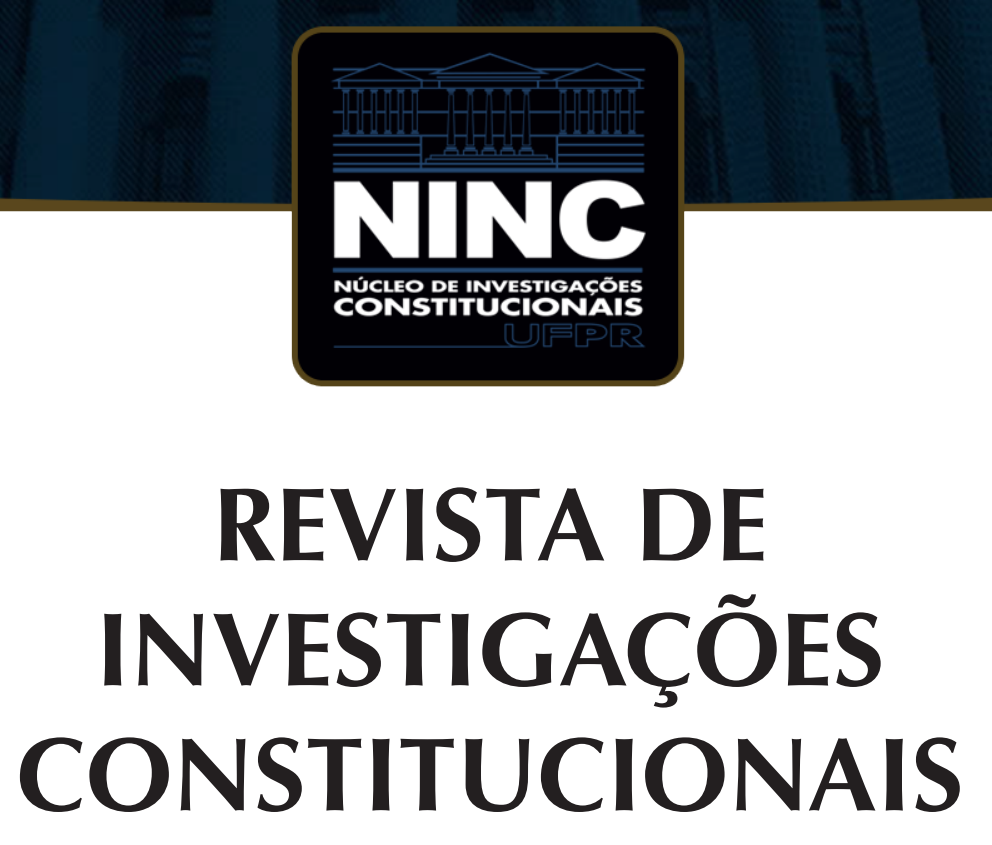

JOURNAL OF CONSTITUTIONAL RESEARCH

vol. 8 | n. 3 | setembro/dezembro 2021 | ISSN 2359-5639 | Periodicidade quadrimestral Curitiba | Núcleo de Investigações Constitucionais da UFPR | www.ninc.com.br 


\title{
O estado de coisas inconstitucional e o compromisso significativo enquanto instrumentos do constitucionalismo dialógico no Brasil: virtudes e limites
}

\section{The unconstitutional state of affairs and the significant commitment as instruments of the dialogical Constitutionalism in Brazil: virtues and limits}

\author{
JULIANA MARIA BORGES MAMEDE ${ }^{1, *}$ \\ ' Universidade de Fortaleza (Fortaleza, Ceará, Brasil) \\ julianamamede@unifor.br \\ https://orcid.org/0000-0002-9234-1157
}

\section{HELIO DAS CHAGAS LEITÃO NETO ${ }^{1, * *}$}

' Universidade de Fortaleza (Fortaleza, Ceará, Brasil) helioleitao@hlpadvogados.com.br https://orcid.org/0000-0003-4378-467X

\section{FRANCISCO LUCIANO LIMA RODRIGUES $1,11, * * * *$}

' Universidade de Fortaleza (Fortaleza, Ceará, Brasil) " Universidade Federal do Ceará (Fortaleza, Ceará, Brasil) lucianolima@unifor.br

https://orcid.org/0000-0003-3409-970X

Recebido/Received: 17.04.2020 / April 17 ${ }^{\text {th }}, 2020$ Aprovado/Approved: 08.03.2021 / March 8 ${ }^{\text {th }}, 2021$

\footnotetext{
Como citar esse artigo/How to cite this article: MAMEDE, Juliana Maria Borges; LEITÃO NETO, Helio das Chagas; RODRIGUES, Francisco Luciano Lima. O estado de coisas inconstitucional e o compromisso significativo enquanto instrumentos do constitucionalismo dialógico no Brasil: virtudes e limites. Revista de Investigações Constitucionais, Curitiba, vol. 8, n. 3, p. 807-835, set./dez. 2021. DOI: 10.5380/rinc.v8i3.72953.

" Professora e Coordenadora do Curso de Direito da Universidade de Fortaleza (Fortaleza-CE, Brasil), vinculada ao Centro de Ciências Jurídicas. Mestre em Direito Constitucional pela Universidade de Fortaleza e Doutoranda em Direito Constitucional pela Universidade de Fortaleza - UNIFOR. E-mail: julianamamede@unifor.br.

"* Doutorando em Direito Constitucional pela Universidade de Fortaleza - UNIFOR (Fortaleza-CE, Brasil). Mestre em Direito Constitucional pela Universidade de Fortaleza - UNIFOR. Professor do Curso de Direito da Universidade Sete de Setembro. Advogado. Atualmente é Conselheiro Federal da OAB/CE. Foi Secretário de Justiça e Cidadania do Estado do Ceará no período de 2015-2017. Presidente da OAB/CE nos períodos 2004-2006 e 2007-2009. E-mail: helioleitao@hlpadvogados.com.br.

**** Professor Titular do Programa de Pós-Graduação em Direito Constitucional (Mestrado/Doutorado) da Universidade de Fortaleza (Fortaleza-CE, Brasil). Professor Adjunto da Faculdade de Direito da Universidade Federal do Ceará (Fortaleza-CE, Brasil). Doutor em Direito pela Universidade Federal de Pernambuco e Mestre em Direito pelo Universidade Federal do Ceará. Desembargador do Tribunal de Justiça do Estado do Ceará. E-mail: lucianolima@unifor.br.
} 
Resumo

A inquestionável precariedade do sistema penitenciário brasileiro, discutida na ADPF 347/2015, levou o Supremo Tribunal Federal, no julgamento da medida cautelar, a declarar o estado de coisas inconstitucional, inaugurando-se, assim, um debate de relevo perante a referida Corte, que impõe a discussão, a reflexão e, possivelmente, a revisão de conceitos e teorias já arraigados, como a questão da separação de poderes e da legitimidade democrática do Poder Judiciário, especialmente no tocante à concepção, implementação e monitoramento de políticas públicas, o que refrata, diretamente, na relação da judicial review ante o sistema democrático. Considerando a envergadura do debate e das alternativas propostas para a resolução de problemas estruturais, é que se desenvolveu o presente estudo com o propósito de analisar a viabilidade da prática do constitucionalismo dialógico e a celebração do compromisso significativo, uma vez reconhecido o estado de coisas inconstitucional. Nessa linha, coloca-se a necessidade de construção de um debate aberto entre as instâncias eletivas com a Suprema Corte como forma de se buscar a construção de consensos capazes de superar desafios comuns, com respeito à ordem constitucional. Para tanto, realizou-se pesquisa bibliográfico-documental, revelando-se esta como uma pesquisa pura, qualitativa e exploratória.

Palavras-chave: estado de coisas inconstitucional; constitucionalismo dialógico; compromisso significativo; separação de poderes; democracia.

\section{Abstract}

The unquestionable precariousness of the Brazilian penitentiary system, discussed in ADPF 347/2015, led the Federal Supreme Court, in the judgment of the injuction, to declare the unconstitutional state of affairs, thus inaugurating a relevant discuss in the Court, which calls for discussion, reflection and, possibly, a review of concepts and theories already established, such as the question of the powers separation and the democratic legitimacy of the Judiciary, especially with regard to the conception, implementation and monitoring of public policies which refracts, directly, in the relation of judicial review on the democratic system. Considering the scope of the debate and the alternatives proposed for the resolution of structural problems is developed the present study, with the purpose of verifying the feasibility of the practice of dialogical constitutionalism and the celebration of the meaningful engagement, once recognized the unconstitutional state of affairs. In this sense, it is necessary to build an open debate between the elective bodies and the Supreme Court, as a way to the construction of consensus able to overcome common challenges, related to the constitutional order. For this purpose, a bibliographic-documentary research was conducted, revealing itself as a pure, qualitative and exploratory research.

Keywords: unconstitutional state of affairs; dialogical constitutionalism; meaningful engagement; separation of powers; democracy.

\section{SUMÁRIO}

1. Introdução; 2. O estado de coisas inconstitucional na Colômbia; 2.1. O estado de coisas inconstitucional colombiano: contexto fático, pressupostos e desenvolvimento; 2.2. Críticas ao estado de coisas inconstitucional colombiano; 3. O estado de coisas inconstitucional no Brasil; 3.1. O estado de coisas inconstitucional no Brasil: contexto fático e pressupostos verificáveis na crise penitenciária brasileira; 3.2. Uma análise da pertinência das críticas ao estado de coisas inconstitucional colombiano em face do estado de coisas inconstitucional brasileiro; 4 . O constitucionalismo dialógico e os horizontes de uma reconfiguração da experiência brasileira do estado de coisas inconstitucional; 4.1. Constitucionalismo Dialógico e Jurisdição Constitucional Dialógica; 4.2. O compromisso significativo Sul-Africano e a proposta de sua recepção no Brasil: uma convergência ante o ECI brasileiro?; 5. Conclusão; 6 . Referências.

\section{INTRODUÇÃO}

A precariedade do sistema penitenciário brasileiro, noticiada cotidianamente pelos mais diversos canais de informação nacional e internacional, dada a sua complexidade e alcance, após levada à apreciação do Poder Judiciário em demandas de 
natureza subjetiva, chegou ao Supremo Tribunal Federal através da ADPF 347/2015', ajuizada pelo Partido Socialismo e Liberdade - PSOL. Com fundamento em documentos oficiais, nos quais restou reconhecida e comprovada a violação massiva e generalizada de direitos fundamentais, o descaso das instâncias eletivas para com a questão penitenciária, bem como inspirada no construto da Corte Constitucional Colombiana, a qual delineou os contornos básicos e pressupostos necessários à configuração daquilo que viria a ser denominado de "estado de coisas inconstitucional", a ADPF 347/2015 inaugurou um debate de relevo perante o Supremo Tribunal Federal que impõe a discussão, a reflexão e, possivelmente, a revisão de conceitos e teorias já arraigados, como a questão da separação de poderes e da legitimidade democrática do Poder Judiciário, especialmente no tocante à concepção, implementação e monitoramento de políticas públicas, o que refrata na relação da judicial review ante o sistema democrático.

Assim, declarado o estado de coisas inconstitucional no julgamento da cautelar da ADPF 347/2015 e considerando ser a aludida decisão incipiente e, talvez por isso, desprovida de uma maior técnica e apuro, bem como em virtude de anuir-se com a importância da questão em virtude de seus reflexos sociais e do malferimento a preceitos constitucionais fundamentais, perscrutou-se alternativas viáveis (neste momento, ainda em um plano teórico) à superação da crise estrutural do sistema penitenciário brasileiro a partir do relato de experiências exógenas, notadamente da Colômbia e da África do Sul, pretendendo-se, pois, apresentar uma reflexão acerca da possibilidade de um constitucionalismo dialógico uma vez declarado o estado de coisas inconstitucional e celebrado o compromisso significativo.

Essas práticas refletem uma releitura sobre o papel da jurisdição constitucional diante de temas de elevada complexidade e que interferem na relação da judicial review ante o sistema democrático. Nessa linha, coloca-se a necessidade de construção de um debate aberto entre as instâncias eletivas com a Suprema Corte como forma de se buscar a construção de consensos capazes de superar desafios comuns, com respeito à ordem constitucional.

Para tanto, utilizou-se de uma pesquisa do tipo bibliográfica e documental. Em relação à tipologia da pesquisa, esta é, segundo a utilização dos resultados, pura, pois visa ampliar o conhecimento sobre o tema, ao passo que, quanto à abordagem, mostra-se qualitativa, uma vez que apresentará um estudo sobre fenômeno específico. Relativamente aos objetivos, trata-se de pesquisa exploratória, definindo objetivos e buscando maiores informações sobre o tema em questão.

O presente artigo divide-se em três seções: na primeira seção objetiva-se, a partir de uma reflexão acerca de decisões da Corte Constitucional Colombiana que

\footnotetext{
1 BRASIL. Supremo Tribunal Federal. ADPF 347. Disponível em: http://portal.stf.jus.br/processos/detalhe. asp?incidente=4783560. Acesso em: 28 abr. 2018.
} 
declararam o estado de coisas inconstitucional, apresentar o contexto fático que permitiu o reconhecimento do estado de graves, massivas e sistemáticas violações a direitos fundamentais, o que levou a Corte a reconhecer a existência de litígios estruturais a ensejarem a determinação de medidas necessárias à reconfiguração da realidade no sentido de ajustá-la aos ditames constitucionais.

Ato contínuo, passa-se a perquirir acerca de como se deu a recepção da aludida técnica decisória, bem como se a mesma se adéqua ao contexto fático existente no Brasil. Ademais, pretende-se verificar se o reconhecimento do estado de coisas inconstitucional se apresentaria como efetivo instrumento de superação da crise do sistema penitenciário nacional.

Por fim, abordar-se-á o marco teórico proposto como uma revisão do sistema forte de controle de constitucionalidade a partir da reavaliação do sistema de freios e contrapesos, nos limites do chamado constitucionalismo dialógico, conducente a uma jurisdição constitucional fraca ante os poderes eletivos, como forma de se privilegiar o princípio democrático. Em seguida, analisar-se-á a pertinência do estado de coisas inconstitucional e do compromisso significativo (meaningful engagement) para tal finalidade, com especial foco para o uso brasileiro do estado de coisas inconstitucional na ADPF 347/2015.

\section{O ESTADO DE COISAS INCONSTITUCIONAL NA COLÔMBIA}

Na presente seção objetiva-se, a partir de uma reflexão acerca de decisões da Corte Constitucional Colombiana que declararam o estado de coisas inconstitucional, apresentar o contexto fático que permitiu o reconhecimento do estado de graves, massivas e sistemáticas violações a direitos fundamentais, o que levou a Corte a reconhecer a existência de litígios estruturais a ensejarem a determinação de medidas necessárias à reconfiguração de uma dada ordem social no sentido de ajustá-la aos ditames constitucionais.

\subsection{O estado de coisas inconstitucional colombiano: contexto fático, pressupostos e desenvolvimento}

As decisões da Corte Constitucional Colombiana, prolatadas na Sentencia de Unificación (SU) - 559, de 1997 (Caso dos Docentes Municipais), na Sentencia de Tutela (ST) - 153, de 1998 (Caso do Sistema Carcerário Colombiano - ver ainda Sentencias de Tutela (ST) - 388, de 2013 e 762, de 2015, sobre a permanência da situação) e na Sentencia (ST) - 025, de 2004 (Caso do "deslocamento forçado", com a retenção de jurisdição pela Corte para a garantia da implementação total de suas ordens), apresentam-se como leading cases não apenas da afirmação, mas também das transformações por que passou o instituto do estado de coisas inconstitucional. 
Assim, partindo-se da necessidade de atuação dos poderes estatais para a retificação do quadro de violações, a Corte Constitucional Colombiana, na SU - 559, de 1997, declarou, pela primeira vez, o estado de coisas inconstitucional. No caso ora reportado, pôs-se em discussão o direito de professores municipais beneficiarem-se de coberturas de saúde e de seguridade social, uma vez que efetivamente vinham contribuindo, obrigatoriamente, com 5\% dos seus subsídios para o Fundo de Prestación Social, apresentando-se, como contra-argumento ao direito pleiteado pelos professores, a alegativa das autoridades locais de escassez de recursos orçamentários.

A Corte Constitucional Colombiana, ao apreciar o caso, não se deteve em uma análise dos direitos subjetivos dos professores, indo além, na medida em que reconheceu falhas estruturais e concedeu medidas que visavam à tutela dos direitos fundamentais em sua acepção objetiva ${ }^{2}$. Para tanto, iniciou por notificar as autoridades públicas acerca de uma situação de patente violação à Constituição, sem, contudo, aceitar imiscuir-se diretamente na problemática financeiro-orçamentária trazida, o que se pode evidenciar com o estabelecimento de um prazo razoável (verdadeiro conceito jurídico indeterminado) para que as autoridades públicas competentes sanassem as violações, não se estabelecendo qualquer obrigatoriedade aos órgãos de controle para acompanharem a decisão judicial. Observa Campos ${ }^{3}$ que, "além de sanar problema estrutural que promovia violação massiva de direitos fundamentais, a Corte também agiu em estratégia de defesa de seu prestígio social contra possível enfraquecimento de sua capacidade e qualidade de julgamento decorrente de acúmulo de processos".

Por sua vez, na ST - 153, de 1998, a Corte se debruçou sobre o quadro de superlotação das penitenciárias colombianas, assim como sobre a violação a direitos fundamentais daí decorrente, tendo reconhecido as unidades prisionais da Colômbia como ambientes inóspitos e incapazes, portanto, de promoverem a ressocialização dos presos.

Observe-se que nessa decisão a Corte declarou que os males que acometem o sistema penitenciário colombiano requerem o esforço coordenado de distintos ramos e órgãos do Poder Público, tendo reconhecido, ainda, que a matéria estava completamente alheia à agenda política, razão pela qual a Corte Constitucional Colombiana entendeu que o juiz constitucional estaria "obrigado a assumir o clamor das minorias esquecidas, isto é, daqueles grupos que dificilmente têm acesso aos organismos políti$\cos ^{\prime \prime}{ }^{4}$, viabilizando, assim, a tutela dos direitos fundamentais em uma acepção objetiva.

2 CAMPOS, Carlos Alexandre de Azevedo. Estado de Coisas Inconstitucional. Salvador: JusPodivm, 2016, p. 121.

3 CAMPOS, Carlos Alexandre de Azevedo. Estado de Coisas Inconstitucional. Salvador: JusPodivm, 2016, p. 125.

4 CAMPOS, Carlos Alexandre de Azevedo. Estado de Coisas Inconstitucional. Salvador: JusPodivm, 2016, p. 131. 
Inobstante o reconhecimento do estado de coisas inconstitucional na ST - 153, de 1998, que serviu de marco para a produção de uma reestruturação administrativa e de políticas públicas, bem como para a designação de um acompanhamento específico por parte de instituições de controle do Executivo ${ }^{5}$, há registros de que a pretendida eficácia da decisão não foi alcançada em sua integralidade ${ }^{6}$, voltando a Corte Constitucional Colombiana a reconhecer que o sistema penitenciário colombiano se apresentava contrário à ordem constitucional, com inegável violação de direitos fundamentais, na ST - 388, de 2013, e na ST - 762, de 2015, razão pela qual, nesta última decisão, a Corte entendeu que políticas públicas mais efetivas deveriam ser formuladas, primando por um foco maior no controle de sua execução.

Em outra situação, na ST - 025, de 2004, que teve por objeto o caso do deslocamento interno forçado em virtude da violência que assolava a Colômbia, tem-se aquela decisão que é considerada como a de maior relevância em razão dos avanços obtidos ${ }^{7}$. $\mathrm{Na}$ hipótese vertente, reconhecida a grave ofensa a direitos fundamentais dos deslocados, bem como atentando-se às experiências passadas, especialmente ante as dificuldades de sua concretização, como, por exemplo, na ST - 153, acima referida, a Corte reteve jurisdição a fim de monitorar e garantir o cumprimento das decisões em sua integralidade, observando-se, outrossim, a demanda de um maior acompanhamento e supervisão das decisões.

Nesse processo de monitoramento não se pode olvidar a importância do processo de acompanhamento da eficácia da decisão do estado de coisas inconstitucional por meio das decisões de sequência (também conhecidas por autos), as quais viabilizam observar a necessidade de informações e ações concretas de atores específicos nas decisões estruturais, permitindo-se, com isso, uma maior adequação e efetividade de tais decisões face a complexidade e dinamicidade das questões nela versadas, uma vez que as intervenções judiciais estruturais importam em readequações orçamentárias e tendentes a modificar instituições governamentais em mau funcionamento ${ }^{8}$. Ressalta-se, por fim, na ST - 025, de 2004, a postura da Corte ao reconhecer a necessidade de romper

\footnotetext{
5 HERNÁNDEZ, Clara Inés Vargas. La garantía de la dimensión objetiva de los derechos fundamentales y labor del juez constitucional colombiano en sede de acción de tutela: el llamado "estado de cosas inconstitucional". Revista del Centro de Estudios Constitucionales, ano 1, n. 1, p. 203-228, 2003. Disponível em: https:// www.redalyc.org/articulo.oa?id=82010111. Acesso em: 02 mar. 2019. p. 217-221.

6 HERNÁNDEZ, Clara Inés Vargas. La garantía de la dimensión objetiva de los derechos fundamentales y labor del juez constitucional colombiano en sede de acción de tutela: el llamado "estado de cosas inconstitucional". Revista del Centro de Estudios Constitucionales, ano 1, n. 1, p. 203-228, 2003. Disponível em: https:// www.redalyc.org/articulo.oa?id=82010111. Acesso em: 02 mar. 2019. p. 220 e 221.

7 CAMPOS, Carlos Alexandre de Azevedo. Estado de Coisas Inconstitucional. Salvador: JusPodivm, 2016, p. 142.

8 CAMPOS, Carlos Alexandre de Azevedo. Estado de Coisas Inconstitucional. Salvador: JusPodivm, 2016, p. $152-153$ e 188.
} 
a inércia das autoridades públicas sem invadir, contudo, a esfera de competência das demais instâncias? .

Percebe-se, assim, um aprimoramento no trato da questão pela Corte Constitucional Colombiana, vislumbrando-se o manejo de ordens peremptórias a serem executadas: (i) pelas autoridades públicas, com a elaboração de políticas públicas e ajustes na estrutura administrativo-orçamentária; e, (ii) pelos órgãos de controle, competindo a estes o acompanhamento da execução das medidas. Destaca-se que na situação vertente, a Corte, mesmo identificando a origem das falhas estruturais, não interveio na formulação do conteúdo das políticas públicas, tendo incumbido às instâncias governamentais o dever de concebê-las e executá-las.

Neste sentido, é que se tomando como paradigmas a Sentença de Unificação (SU) - 559, de 1997, a Sentença de Tutela (ST) - 153, de 1998 e, por fim, a Sentença de Tutela (ST) - 025, de 2004, ficou patente a necessidade de atuação da Corte Constitucional quando diante de um quadro que reúna os seguintes pressupostos, tal como esboçado, em definitivo, na ST - 025/04: (i) la vulneración masiva y generalizada de varios derechos constitucionales que afecta a un número significativo de personas; (ii) la prolongada omisión de las autoridades en el cumplimiento de sus obligaciones para garantizar los derechos; (iii) la adopción de prácticas inconstitucionales, como la incorporación de la acción de tutela como parte del procedimiento para garantizar el derecho conculcado; (iv) la no expedición de medidas legislativas, administrativas o presupuestales necesarias para evitar la vulneración de los derechos; (v) la existencia de un problema social cuya solución compromete la intervención de varias entidades, requiere la adopción de un conjunto complejo y coordinado de acciones y exige un nivel de recursos que demanda un esfuerzo presupuestal adicional importante; (vi) si todas las personas afectadas por el mismo problema acudieran a la acción de tutela para obtener la protección de sus derechos, se produciría una mayor congestión judicial ${ }^{10}$.

Conforme acima exposto, é de se ver que muito embora a ST - 025 tenha mencionado a existência de seis requisitos para a declaração do estado de coisas inconstitucional, entende-se, conforme exposto por Campos $^{11}$, que eles podem ser melhor sistematizados em quatro, quais sejam: (i) um quadro de violação grave, massiva e sistemática de direitos fundamentais que alcança um número alto e indeterminado de pessoas; (ii) a omissão reiterada e persistente das autoridades públicas na tutela dos direitos fundamentais, que pode se manifestar nas omissões legislativas, na falta de

9 CAMPOS, Carlos Alexandre de Azevedo. Estado de Coisas Inconstitucional. Salvador: JusPodivm, 2016, p. 149.

10 COLÔMBIA. Corte Constitucional de Colômbia. Sentencia T-025/2004. Disponível em: http://www.corteconstitucional.gov.co/relatoria/2004/T-025-04.htm. Acesso em: 08 jun. 2019.

11 CAMPOS, Carlos Alexandre de Azevedo. Estado de Coisas Inconstitucional. Salvador: JusPodivm, 2016, p. 180-187. 
priorização política do enfrentamento de circunstâncias de relevo para tal estado, em políticas públicas inexistentes ou ineficazes ou mesmo na ausência de coordenação eficaz de ações tendentes a eliminar o quadro de violação dos referidos direitos; (iii) a necessidade de atuação conjunta e coordenada de órgãos e entidades públicas para a superação do quadro de inconstitucionalidades; e, (iv) o provável congestionamento judicial provocado pelo ajuizamento isolado de ações tendentes à preservação dos direitos fundamentais violados individualmente considerados.

De todo o exposto, observa-se que nas ações de tutela que se sucederam, a Corte Constitucional Colombiana vem acumulando experiências e avaliando a eficácia de sua postura, razão pela qual identificam-se decisões que se vão construindo em sentido crescente rumo a uma maior compreensão daquilo que se denomina de litígios estruturais, os quais, em razão da sua natureza e características, exigem instrumentos de tutela próprios a ensejarem remédios estruturais a permitir uma maior concretização da acepção objetiva dos direitos fundamentais, com a consequente ampliação da eficácia das medidas de implementação das decisões e, ao mesmo tempo, obtendo-se uma percepção mais acurada dos limites existentes.

\subsection{Críticas ao estado de coisas inconstitucional colombiano}

Analisando-se as decisões anteriormente referidas, observa-se que a Corte Constitucional Colombiana inaugura uma forma de atuação que lhe autoriza a se imiscuir em questões de competência das instâncias eletivas de poder para, por fim, revelar uma clara interferência em espaços de decisão próprios do Executivo e do Legislativo, especialmente no tocante à necessidade de elaboração e efetivação de políticas públicas, o que revela uma nítida postura ativista, passando a protagonizar papéis políticos, definindo e redefinindo prioridades orçamentárias, agendas políticas, supervisionando e/ou direcionando a atuação das demais esferas de poder. Enfim, a Corte passou a se reconhecer como um dos principais instrumentos de transformação social, avançando, assim, um tanto mais sobre a função das demais instâncias de poder.

Para determinado segmento doutrinário, tal atuação enseja críticas de ordem democrática e de violação à teoria da separação de poderes na medida em que um órgão sem maior legitimidade democrática se sobrepõe às demais instâncias de poder sem perseverar no sentido de se abster de interferir em tais questões, deixando que as instâncias eletivas se articulem com vistas à superação do quadro de inconstitucionalidades ou mesmo que demandem ou aceitem uma atuação jurisdicional dialógica, o que seria mais condizente com estados democráticos que privilegiam a separação de poderes.

Este déficit democrático da jurisdição constitucional se expressa pela ausência de um processo político que permita a participação em igualdade de condições de 
defensores e opositores das decisões políticas, deixando-se ao cargo de instâncias sem a correspondente responsabilidade eletiva a definição da controvérsia ${ }^{12}$. O peso desses óbices quanto à legitimidade democrática da jurisdição constitucional e seu possível equacionamento serão tratados adiante com mais vagar.

Ocorre, contudo, que, diante de uma paralisação das instâncias eletivas de poder, não poderia a Corte Constitucional Colombiana assumir outra postura senão a de intervir em prol da tutela dos direitos fundamentais; entretanto, os resultados foram contestáveis, de início.

De fato, ao reconhecer que as críticas quanto ao déficit democrático da jurisdição constitucional e à falta de condições institucionais para o desenho e a implementação de políticas públicas - ou, mesmo, para assegurar a eficácia de suas decisões, dada a dependência de outras instituições governamentais - possuem alguma pertinência, Iturralde ${ }^{13}$ não deixa de observar que a ineficácia das primeiras decisões sobre o estado de coisas inconstitucional deveu-se ao desígnio da Corte de tentar a solução de casos estruturais a partir da adoção do estado de coisas inconstitucional, o que levou a edição de ordens ambiciosas, muito detalhistas e demasiado audazes em certos casos, vindo a superar as possibilidades do Executivo e do Legislativo. O resultado desse ativismo expansivo, com fulcro na transformação social, findou por deslegitimar a decisão gerando resistência por parte dos demais poderes e esferas decisórias.

Por outro lado, a ST - 153 não deixou de sofrer críticas pelo que representou em termos eficaciais, de logo, para a situação da massiva violação de direitos fundamentais na Colômbia. Assim, observa-se que o recorte do caso, tal como deduzido ante a Corte Constitucional e seu posterior trato nesses termos, viabiliza uma leitura transmutadora, o que poderia ser suficiente para que se esvazie a almejada eficácia do instituto ali delineado ${ }^{14}$.

Nesse sentido, três traços são marcantes para a construção do caso tal como veio a julgamento, interferindo sobre os resultados da decisão. Em breve repasse, observa-se que tal leitura transmutadora decorre: (i) da escolha da dimensão institucional (estrutural/objetiva) sobre a dimensão humana (individual/subjetiva), o que deixa de lado o aspecto humano e próximo em favor de uma leitura institucionalizada e impessoal, colocando-se o destaque sobre a estrutura antes da pessoa e seu sofrimento, de modo a

\footnotetext{
12 WALDRON, Jeremy. Control de Constitucionalidad y Legitimidad Política. Dikaion, v. 27, n. 1, p. 7-28, 2018. p. $16-17$ e 22.

13 ITURRALDE, Manuel. Acceso a la justicia constitucional en Colombia: oportunidades y retos para la transformación social y política. In: MALDONADO, Daniel Bonilla (Ed.). Constitucionalismo del Sur Global. Bogotá: Siglo del Hombre Editores, 2015. p. 443-493. p. 489-491.

14 ARIZA, Libardo José. Los derechos econômicos, sociales y culturales de las personas presas y la intervención de la Corte Constitucional en el sistema penitenciario colombiano. In: MALDONADO, Daniel Bonilla (Ed.). Constitucionalismo del Sur Global. Bogotá: Siglo del Hombre Editores, 2015. p. 169-204. p. 191.
} 
tornar tolerável, como um dado simples da realidade, o que não seria aceitável ${ }^{15}$; (ii) da ausência de uma autocrítica das políticas jurisdicionais até então adotadas (por exemplo, no superencarceramento) para que se faça aceitável a dimensão temporal que se demanda para o enfrentamento das condições motivadoras do estado de coisas inconstitucional, com a consequente exigência de que as pessoas encarceradas suportem a carga de condições de vida sub-humanas até que se reforme o sistema, passando ao largo das implicações sobre a exigibilidade imediata dos direitos fundamentais das pessoas presas $^{16}$; e, (iii) da escolha dos remédios estruturais a serem adotados, pois se acredita que, uma vez que se modernizem as prisões, melhorem seus aparatos administrativos, garanta-se uma boa gestão, amplie-se sua capacidade de ação e sua segurança, ter-se-ia, necessariamente, o respeito das pessoas presas ${ }^{17}$, o que, de fato, não se verifica como um efeito causal, consoante se perceberia na ST - 388, de 2013, e na ST - 762, de 2015.

A crítica de Ariza $^{18}$ assinala o efeito simbólico da decisão no estabelecimento de um dever estóico de aceitação, por parte das pessoas presas, de suportar as condições de reclusão que a mesma Corte considera infra-humanas, até que se retifiquem tais condições, o que parece comprometer a decisão quanto a eficácia da tutela dos direitos fundamentais.

Por trás desse sentido simbólico, destacam-se duas premissas políticas do penalismo neoliberal que parecem orientar a decisão, quais sejam: (i) a consideração do delito como pura manifestação do livre-arbítrio, sem maior relação com o contexto social e econômico em que vive o indivíduo, a exigir do infrator que aceite seu erro e assuma o ônus degradante de sua retificação, "bajo condiciones infrahumanas de reclusión mientras se alcanza el estado de cosas imaginado por los jueces"; e, (ii) a concepção da pena como meio de neutralização de ameaças ${ }^{19}$.

\footnotetext{
15 ARIZA, Libardo José. Los derechos econômicos, sociales y culturales de las personas presas y la intervención de la Corte Constitucional en el sistema penitenciario colombiano. In: MALDONADO, Daniel Bonilla (Ed.). Constitucionalismo del Sur Global. Bogotá: Siglo del Hombre Editores, 2015. p. 169-204. p. 193-194.

16 ARIZA, Libardo José. Los derechos econômicos, sociales y culturales de las personas presas y la intervención de la Corte Constitucional en el sistema penitenciario colombiano. In: MALDONADO, Daniel Bonilla (Ed.). Constitucionalismo del Sur Global. Bogotá: Siglo del Hombre Editores, 2015. p. 169-204. p. 194-195.

17 ARIZA, Libardo José. Los derechos econômicos, sociales y culturales de las personas presas y la intervención de la Corte Constitucional en el sistema penitenciario colombiano. In: MALDONADO, Daniel Bonilla (Ed.). Constitucionalismo del Sur Global. Bogotá: Siglo del Hombre Editores, 2015. p. 169-204. p. 195-196.

18 ARIZA, Libardo José. Los derechos econômicos, sociales y culturales de las personas presas y la intervención de la Corte Constitucional en el sistema penitenciario colombiano. In: MALDONADO, Daniel Bonilla (Ed.). Constitucionalismo del Sur Global. Bogotá: Siglo del Hombre Editores, 2015. p. 169-204. p. 196.

19 ARIZA, Libardo José. Los derechos econômicos, sociales y culturales de las personas presas y la intervención de la Corte Constitucional en el sistema penitenciario colombiano. In: MALDONADO, Daniel Bonilla (Ed.). Constitucionalismo del Sur Global. Bogotá: Siglo del Hombre Editores, 2015. p. 169-204. p. 196.
} 
De fato, após analisar as medidas implementadas a partir da decisão na ST - 153, Ariza ${ }^{20}$ constata que se verifica um forte impacto estrutural no sistema carcerário sem que se tenha traduzido no gozo efetivo de direitos para as pessoas presas, em razão da forma como se construiu o recorte do caso. Na verdade, assinala o autor, a situação resultou agravada e todo o ônus da reforma estrutural recaiu sobre uma população penitenciária submetida, cotidianamente, a violação de seus direitos fundamentais.

\section{O ESTADO DE COISAS INCONSTITUCIONAL NO BRASIL}

Partindo-se das considerações acima, passa-se a perquirir acerca de como ocorreu a recepção da aludida técnica decisória, bem como se a mesma se adéqua ao contexto fático existente no Brasil. Ademais, pretende-se verificar se o reconhecimento do estado de coisas inconstitucional se apresentaria como efetivo instrumento de superação da crise do sistema penitenciário nacional.

\subsection{O estado de coisas inconstitucional no Brasil: contexto fático e pressupostos verificáveis na crise penitenciária brasileira}

A recepção do estado de coisas inconstitucional no Brasil se deu através da ADPF n³47, na qual o Partido Socialismo e Liberdade (PSOL) pugna pela declaração do estado de coisas inconstitucional relativamente ao sistema carcerário brasileiro, vislumbrando possível alternativa à superlotação do sistema penitenciário e à superação das condições sub-humanas que são impostas aos detentos, acarretando graves violações aos direitos fundamentais, especialmente à dignidade da pessoa humana, como se passa a analisar.

Consoante o Levantamento Nacional de Informações Penitenciárias - Infopen, Junho/2016 21 , a população prisional no Brasil atingiu a marca de 726.712 pessoas, ocasionando um déficit de 358.663 vagas no sistema. Ao atingir essa marca, o Brasil passou a ter a terceira maior população carcerária do mundo ${ }^{22}$, observando-se, no período de 1990 a 2016, um crescimento de $707 \%$ da população prisional. Ressalta-se, ainda, que $40 \%$ das pessoas presas no Brasil, em junho de 2016 , eram presos provisórios, não havendo sido submetidas a julgamentos e, consequentemente, condenadas.

\footnotetext{
20 ARIZA, Libardo José. Los derechos econômicos, sociales y culturales de las personas presas y la intervención de la Corte Constitucional en el sistema penitenciario colombiano. In: MALDONADO, Daniel Bonilla (Ed.). Constitucionalismo del Sur Global. Bogotá: Siglo del Hombre Editores, 2015. p. 169-204. p. 200-201.

21 BRASIL. Ministério da Justiça e Segurança Pública. Departamento Penitenciário Nacional - DEPEN. Levantamento Nacional de Informações Penitenciárias: Atualização - Junho 2016. Disponível em: https://tinyurl. com/ycg68vox. Acesso em: 28 abr. 2018.

22 BRASIL. Ministério da Justiça e Segurança Pública. Departamento Penitenciário Nacional - DEPEN. Agência Brasil. Com 726 mil presos, Brasil tem terceira maior população carcerária do mundo. Disponível em: https://tinyurl.com/y89ro2v2. Acesso em: 28 abr. 2018.
} 
O Conselho Nacional de Justiça, em julho do ano corrente, divulgou relatório que contabiliza mais de 800 mil presos, dos quais quase $50 \%$ não têm condenação ${ }^{23}$. Destaca-se que do aludido levantamento estão excluídos os presos com tornozeleira eletrônica e os que estão em regime aberto domiciliar. À superlotação do sistema penitenciário somam-se as condições estruturais das unidades prisionais brasileiras que, nem mesmo remotamente, atendem à função ressocializadora da pena, dado o tratamento degradante a que são submetidos os presos, em nítida ofensa aos preceitos fundamentais constitucionais.

O expressivo número de pessoas encarceradas, desprovidas de educação, trabalho, alimentação e ambiente hígido, submetidas constantemente a maus tratos e torturas ${ }^{24}$ historicamente favoreceram e ainda permanecem a catalisar rebeliões no interior do sistema penitenciário, fazendo crescer o sentimento de insegurança dentro das unidades prisionais, o que, em larga medida, passou a contribuir para o surgimento e para a expansão das facções criminosas, agravando a situação dentro dos mencionados estabelecimentos restritivos de liberdade.

A prisão se transforma normalmente em estado de encarceramento sem intervenção da magistratura. Se pode permanecer por tempo ilimitado em espera de julgamento. Se pode permanecer no cárcere também depois que são expirados os termos de custódia cautelar. Se pode permanecer no cárcere sem que o juiz da execução da pena efetue nenhuma averiguação e nenhum controle. Se pode ser recluso em um cárcere no qual a polícia penitenciária não efetua controle sobre o deslocamento de prisioneiros. Se pode ser enviado para um cárcere no qual uma parte é ocupada por membros da organização a que pertence o prisioneiro e uma outra ocupada pela associação criminosa rival. Se pode fazer de modo que algumas zonas internas do cárcere sejam impenetráveis. Se pode fazer de modo que uma banda ocupe o espaço da outra e exija a sua vingança. Pode acontecer que por dias inteiros a polícia não entre no cárcere onde acontece uma guerra entre facções ${ }^{25}$.

Apenas a título ilustrativo, pontua-se que as facções criminosas Comando Vermelho e Primeiro Comando da Capital tiveram o seu berço no interior do sistema penitenciário, respectivamente, no Complexo Penitenciário Frei Caneca (Presídio da Ilha

\footnotetext{
23 BRASIL. Conselho Nacional de Justiça. Disponível em: https://paineis.cnj.jus.br/QvAJAXZfc/opendoc.htm?document=qvw_l\%2FPainelCNJ.qvw\&host=QVS\%40neodimio03\&anonymous=true\&sheet=shBNMPIIMAPA. Acesso em: 12 set. 2019.

24 Veja-se o Relatório de Missão ao Estado do Ceará elaborado pelo Mecanismo Nacional de Prevenção e Combate à Tortura.

25 DE GIORGI, Raffaele; VASCONCELOS, Diego de Paiva. Os fatos e as declarações: Reflexões sobre o estado de ilegalidade difusa. Revista Direito \& Praxis, Rio de Janeiro, v. 9, n. 1, p. 408-453, 2018. Disponível em: http:// www.scielo.br/pdf/rdp/v9n1/2179-8966-rdp-9-1-480.pdf. Acesso em: 03 jun. 2019. p. 497.
} 
Grande - Angra dos Reis - RJ), nos fins da década de 1970 e início da década de $1980^{26}$ e na Casa de Custódia e Tratamento de Taubaté/SP, em 31 de agosto de 199327, contestando o tratamento degradante dispensado aos presos, bem como exigindo melhores condições para as unidades prisionais.

Nesse cenário, observa-se a pertinência da observação de Castoriadis ${ }^{28}$, segundo a qual o conjunto de condições de privação e opressão, resultante de uma estrutura solidificada, global, material e institucional, de economia, de poder e de ideologia, como indução, mistificação, manipulação e violência desafiam e tolhem a autonomia individual, com a consequente alienação do sujeito ante valores que deveriam ser superiores, mas que findam excluídos de sua realidade.

Diante das falhas estruturais apresentadas pelo sistema penitenciário é que o PSOL - com fundamento na Comissão Parlamentar de Inquérito da Câmara dos Deputados (2007-2009), que teve por objeto o sistema prisional brasileiro, e no Parecer da Clínica de Direitos Fundamentais da Faculdade de Direito da Universidade do Estado do Rio de Janeiro (Clínica UERJ Direitos) - ajuizou a ADPF n³47/2015, na qual o Supremo Tribunal Federal reconheceu serem as unidades prisionais brasileiras ambientes inóspitos e degradantes, que acarretam uma massiva e sistemática violação dos direitos fundamentais, razão pela qual a Corte, ao julgar a medida cautelar da referida ação, declarou, pela primeira vez, o estado de coisas inconstitucional no Brasil.

O Supremo Tribunal Federal inspirou-se na Corte Constitucional Colombiana para definir os pressupostos necessários à declaração do estado de coisas inconstitucional, sendo eles: (i) um quadro de violação grave, massiva e sistemática de direitos fundamentais que alcança um número alto e indeterminado de pessoas; (ii) a omissão reiterada e persistente das autoridades públicas na tutela dos direitos fundamentais, que pode manifestar-se nas omissões legislativas, na falta de priorização política do enfrentamento de circunstâncias de relevo para tal estado, em políticas públicas inexistentes ou ineficazes ou mesmo na ausência de coordenação eficaz de ações tendentes a eliminar o quadro de violação dos referidos direitos; (iii) a necessidade de atuação conjunta e coordenada de órgãos e entidades públicas para a superação do quadro de inconstitucionalidades; e, (iv) o provável congestionamento judicial provocado pelo ajuizamento isolado de ações tendentes à preservação dos direitos fundamentais violados individualmente considerados.

A verificação do primeiro pressuposto, violação grave, massiva e sistemática de direitos fundamentais da população encarcerada, se faz a partir da constatação das

26 AMORIM, Carlos. Comando Vermelho: a história do crime organizado. Rio de Janeiro: BestBolso, 2011, p. 94.

27 CHRISTINO, Marcio Sergio; TOGNOLLI, Claudio. Laços de Sangue: a história secreta do PCC. São Paulo: Matrix, 2017, p. 69.

28 CASTORIADIS, Cornelius. A Instituição Imaginária da Sociedade. Trad. Guy Reynaud. Rio de Janeiro: Paz e Terra, 1982, p. 131. 
condições estruturais do sistema penitenciário que viola o princípio da dignidade da pessoa humana, fundamento ético de todos os direitos fundamentais, ao submeter os detentos a torturas e a tratamentos cruéis e degradantes, conforme restou demonstrado em farta documentação acostada à ADPF 347/2015.

Já quanto ao segundo pressuposto, condizente à omissão reiterada e persistente das autoridades públicas na tutela dos direitos fundamentais, que pode se manifestar, dentre tantas outras formas, em políticas públicas inexistentes ou ineficazes, ou mesmo na ausência de coordenação eficaz de ações tendentes a eliminar o quadro de violação dos referidos direitos, bem como na verificação do quantitativo de prisões provisórias decretadas e no excesso de prazo no cumprimento da pena, resta evidenciado a partir da verificação de que a referida temática não é priorizada na agenda política.

A realidade do sistema prisional leva a crer, pois, em um descaso das instâncias primariamente competentes para a concepção e implementação de políticas públicas no sentido de solver ou mesmo minimizar a precariedade do sistema penitenciário nacional; ao invés, privilegia-se o encarceramento como uma medida factível e eficaz de manutenção da segurança pública, bem ao gosto do penalismo neoliberal mencionado acima. No entanto, os números refutam toda e qualquer tentativa de camuflar a atual situação da segurança pública e do sistema penitenciário brasileiro, uma vez que tal medida, embora de uso crescente, por si só é inócua, já que não se observa uma redução dos índices de criminalidade e, consequentemente, de detenções, o que termina por agravar a crise do sistema penitenciário, ressaltando a inoperância das instituições estatais e a gestão precária do referido sistema.

No tocante ao terceiro pressuposto, qual seja, a necessidade de atuação conjunta e coordenada de órgãos e entidades públicas para a superação do quadro de inconstitucionalidades, este se evidencia a partir da constatação da complexidade da questão que requer esforços conjuntos e articulados por parte dos órgãos e poderes públicos, assim como da falta de fóruns interinstitucionais articulados de forma eficaz.

Por fim, o quarto pressuposto, referente ao provável congestionamento judicial provocado pelo ajuizamento isolado de ações tendentes à preservação dos direitos fundamentais violados, mostra-se por demais factível, considerando-se o número de pessoas encarceradas submetidas a condições degradantes, muito embora tais questões só consigam ser apreciadas pelo STF através do controle difuso de constitucionalidade, já que o modelo de jurisdição constitucional adotado no Brasil não reconhece legitimidade aos indivíduos para que recorram diretamente ao referido órgão jurisdicional.

É de se ver, pois, que no modelo de jurisdição constitucional adotado pelo Brasil, a ação de descumprimento de preceito fundamental, prevista no art. $102, \S 1^{\circ} \mathrm{da}$ 
Constituição Federal ${ }^{29}$ e regulamentada pela Lei $n^{\circ} 9.882 / 99^{30}$, revela-se como o instrumento mais adequado quando a pretensão for evitar ou reparar lesão a preceito fundamental, resultante de ato do poder público. Ademais, em seu art. 10, a referida lei autoriza ao Tribunal a fixação das condições e o modo de interpretação e aplicação do preceito fundamental, de modo a garantir sua maior efetividade, razão pela qual se reconhece a plena possibilidade de declarar-se o estado de coisas inconstitucional em sede de ADPF.

Neste sentido é que o Projeto de Lei do Senado n 736 , de $2015^{31}$, em seu art. $2^{\circ}$, estabelece que poderá o STF reconhecer o estado de coisas inconstitucional, atendidos, cumulativamente, os pressupostos que se seguem:

I - Constatação de um quadro de violação massiva, generalizada e sistemática de direitos fundamentais, perpetrada pelo Estado, por ação ou omissão, que afete número significativo de pessoas e impeça a preservação do mínimo intangível assegurador da dignidade humana;

II - Falta de coordenação entre medidas legislativas, administrativas, orçamentárias e judiciais, que gere a violação sistemática dos direitos, a perpetuação ou o agravamento dessa situação;

III - Previsão expressa, no texto constitucional, de políticas públicas que necessitem de concretização.

Vale registrar, ainda que de passagem, que o referido projeto de lei estabelece e disciplina o compromisso significativo, além de defini-lo como o "constante intercâmbio entre os segmentos populacionais afetados e o Estado, em que as partes tentam celebrar acordo para a formulação e implementação de programas socioeconômicos que visem a afastar a violação ao preceito fundamental detectada" (art. $2^{\circ}$ do Projeto de Lei do Senado, n 736 , de $2015^{32}$ ), no intuito de se firmar as alternativas em face de conflitos estruturais.

Analisados os pressupostos para a declaração do estado de coisas inconstitucional, percebe-se sua pertinência ante a realidade carcerária brasileira, bem como sua adequação processual ao rito da ADPF, ainda que caibam aprimoramentos legislativos.

\footnotetext{
29 BRASIL. Constituição da República Federativa do Brasil de 1988. Disponível em: http://www.planalto. gov.br/ccivil_03/constituicao/ConstituicaoCompilado.htm. Acesso em: 25 maio 2019.

30 BRASIL. Lei 9.882, de 03 de dezembro de 1999. Dispõe sobre o processo e julgamento da argüição de descumprimento de preceito fundamental, nos termos do $\S 1^{\circ}$ do art. 102 da Constituição Federal. Disponível em: http://www.planalto.gov.br/ccivil_03/leis/19882.htm. Acesso em: 25 maio 2019.

31 BRASIL. Senado Federal. Projeto de Lei do Senado, n 736, de 2015. Disponível em: https://www25.senado.leg.br/web/atividade/materias/-/materia/124010. Acesso em: 25 maio 2019.

32 BRASIL. Senado Federal. Projeto de Lei do Senado, n 736, de 2015. Disponível em: https://www25.senado.leg.br/web/atividade/materias/-/materia/124010. Acesso em: 25 maio 2019. online.
} 
Vê-se, ademais, que o estado de coisas inconstitucional, enquanto técnica decisória apta a promover mudanças estruturais, ou seja, a implementar modificações nas estruturas governamentais em mau funcionamento, pode se apresentar, pelo menos em abstrato, como um instrumento capaz de promover mudanças e ajustes no sistema penitenciário brasileiro, na medida em que se reconhece ao STF o dever de tutelar a ordem objetiva dos direitos fundamentais.

\subsection{Uma análise da pertinência das críticas ao estado de coisas in- constitucional colombiano em face do estado de coisas inconsti- tucional brasileiro}

Convém, contudo, ter em mente ser necessário identificar a exata medida de atuação do STF a fim de que decisões que declarem o estado de coisas inconstitucional sejam efetivas sem usurpar a competência das instâncias eletivas de poder, sob pena de afrontar os princípios democráticos e da separação de poderes, tampouco proferindo decisões ineficazes, que nenhum impacto tenham no contexto fático sobre o qual se pretende interferir e modificar, sob pena de se cair no descrédito.

A temática da crítica sobre a legitimidade da jurisdição constitucional será analisada em item próprio, abaixo, ao se perscrutar as possibilidades de um constitucionalismo dialógico. Entretanto, de logo pode-se examinar se a interferência do STF no caso de referência, até o presente momento, mostrou-se de alguma forma exagerada ou compatível com o ativismo expansivo que se aponta como tendo tido lugar nas primeiras decisões da Corte colombiana.

No caso da ADPF 347/2015, quando do julgamento da cautelar, verificou-se uma tímida atuação do STF, pois, muito embora se tenha reconhecido uma flagrante ofensa a direitos fundamentais no interior das unidades prisionais brasileiras, limitou-se a determinar a realização de mutirões carcerários (que já vinham ocorrendo), de audiências de custódia - já previstas nos artigos 9.3 do Pacto dos Direitos Civis e Políticos e 7.5 da Convenção Interamericana de Direitos Humanos firmados pelo Estado Brasileiro -, bem como impôs o descontingenciamento das verbas destinadas ao Fundo Penitenciário.

Perceba-se que as duas primeiras decisões têm por destinatário o próprio Poder Judiciário, e que a última, inobstante ser direcionada ao Poder Executivo, não impôs a este a obrigatoriedade de apresentar qualquer planejamento para a aplicação das verbas descontingenciadas, o que rechaça qualquer tipo de alegação tendente a afirmar que no caso concreto da ADPF 347/2015, até o presente momento, tenha se verificado ofensa ao princípio democrático ou mesmo à separação de poderes.

Inobstante se tenha o entendimento de que a decisão do STF no julgamento da cautelar da ADPF 347/2015 não tenha extrapolado a sua esfera de competência, são cabíveis as seguintes reflexões: poderia um órgão jurisdicional - ainda que o STF - que 
exerce um papel contramajoritário, desprovido de representatividade popular, imiscuir-se em pautas relativas à coordenação e supervisão de políticas públicas? De outro lado, pondera-se: quem melhor teria condições de conduzir todo esse processo tendente à superação do estado de coisas inconstitucional relativo ao sistema penitenciário brasileiro? Órgãos eletivos e, portanto, dotados de representatividade, mas a privilegiar os custos políticos de suas decisões ou um órgão irresponsável perante o eleitorado, ao qual foi reservada a competência constitucional para a tutela dos direitos fundamentais? Campos ${ }^{33}$ registra:

como dizer da superioridade democrática e da maior capacidade institucional de legisladores e governantes, frente a juízes e cortes, nos casos de absoluta inércia estatal e de falhas estruturais persistentes? Como dizer da participação política de minorias impopulares e estigmatizadas, se presente enorme déficit de representatividade parlamentar? Como admitir a superioridade democrática e institucional de legisladores e de governantes ante um contexto de violação massiva de direitos fundamentais, assistida passivamente por esses agentes políticos?

É certo que a tais questionamentos não se pode ofertar uma resposta absoluta, especialmente se a análise for feita em abstrato. Ressalta-se, no entanto, que no caso da ADPF 347/2015, onde restaram atendidos todos os pressupostos necessários à configuração do estado de coisas inconstitucional, parece ser oportuna e legítima a atuação do STF com as considerações que serão realizadas na seção 3.

Já no que toca à crítica de Ariza $^{34}$ referente à prevalência da dimensão institucional sobre a dimensão humana quanto ao conteúdo da decisão, assim como à exigência de uma larga dose de estoicismo da comunidade carcerária no sentido de suportar as violações de direitos fundamentais durante o tempo necessário para a regularização das condições de encarceramento, pode-se ver a precariedade da decisão brasileira, a qual não exige dos governos federal e estaduais qualquer sorte de planejamento a ser objeto de acompanhamento detalhado pelas instâncias de controle, mantendo sob expectativa o deslinde dos abusos.

Por igual, deixa-se de observar o ambiente de desamparo social em que o crime se forma (descuidando-se do infrator, enquanto pessoa) para sinalizar uma atuação pontual sobre o domínio estrutural e despersonalizado da atuação estatal, crendo-se isso medida suficiente para a correção de rumos necessária. Contudo, dada a precariedade das medidas adotadas, não se pode afirmar, com segurança, se a decisão brasileira

33 CAMPOS, Carlos Alexandre de Azevedo. Estado de Coisas Inconstitucional. Salvador: JusPodivm, 2016, p. 239-240.

34 ARIZA, Libardo José. Los derechos econômicos, sociales y culturales de las personas presas y la intervención de la Corte Constitucional en el sistema penitenciario colombiano. In: MALDONADO, Daniel Bonilla (Ed.). Constitucionalismo del Sur Global. Bogotá: Siglo del Hombre Editores, 2015, p. 169-204. p. 193-196. 
reflete o influxo direto das pautas do que se chamou de penalismo neolibera ${ }^{35}$ nas críticas às decisões da Corte Constitucional da Colômbia nos casos análogos ao brasileiro.

\section{O CONSTITUCIONALISMO DIALÓGICO E OS HORIZONTES DE UMA RECONFIGURAÇÃO DA EXPERIÊNCIA BRASILEIRA DO ES- TADO DE COISAS INCONSTITUCIONAL}

Na presente seção abordar-se-á o marco teórico proposto como uma revisão do sistema forte de controle de constitucionalidade a partir da reavaliação do sistema de freios e contrapesos, nos limites do chamado constitucionalismo dialógico, conducente a uma jurisdição constitucional fraca ante os poderes eletivos como forma de se privilegiar o princípio democrático. Em seguida, analisar-se-á a pertinência do estado de coisas inconstitucional e do compromisso significativo (meaningful engagement) para tal finalidade, com especial foco para o uso brasileiro do estado de coisas inconstitucional na ADPF 347/2015.

\subsection{Constitucionalismo Dialógico e Jurisdição Constitucional Dialó- gica}

Diante da ineficácia das políticas públicas de segurança e de administração penitenciária até o presente, bem como considerando a postura adotada pela Corte Constitucional Colombiana com o reconhecimento do estado de coisas inconstitucional, cumpre analisar suas possibilidades ante o que se vem denominando de constitucionalismo dialógico e sua repercussão na reconfiguração do papel da jurisdição constitucional.

Roberto Gargarella ${ }^{36}$ assinala que o constitucionalismo dialógico se apoia em uma releitura do sistema de freios e contrapesos (inicialmente orientado para evitar e canalizar uma guerra social) no sentido da institucionalização de um diálogo entre iguais a ser desenvolvido entre os poderes estatais, notadamente entre o judiciário e o legislativo, quando da judicial review.

O autor ${ }^{37}$ não deixa de perceber como manifestações dialógicas as decisões originadas de litígios de tipo estrutural que demandam a participação ampliada por

\footnotetext{
35 ARIZA, Libardo José. Los derechos econômicos, sociales y culturales de las personas presas y la intervención de la Corte Constitucional en el sistema penitenciario colombiano. In: MALDONADO, Daniel Bonilla (Ed.). Constitucionalismo del Sur Global. Bogotá: Siglo del Hombre Editores, 2015, p. 169-204. p. 196.

36 GARGARELLA, Roberto. El nuevo constitucionalismo dialógico frente ao sistema de lós frenos y contrapesos. In: GARGARELLA, Roberto (Comp.). Por uma justicia dialógica: el Poder Judicial como promotor de la deliberación democrática. Buenos Aires: Siglo Veintiuno Editores, 2014. p. 119-158. p. 125.

37 GARGARELLA, Roberto. El nuevo constitucionalismo dialógico frente ao sistema de lós frenos y contrapesos. In: GARGARELLA, Roberto (Comp.). Por uma justicia dialógica: el Poder Judicial como promotor de la deliberación democrática. Buenos Aires: Siglo Veintiuno Editores, 2014. p. 119-158. p. 121.
} 
meio de audiências públicas e que rompem com a autocontenção de praxe das Cortes Constitucionais (notadamente na América Latina), comprometendo-se ante violações de direitos que antes não encontravam resposta judicial concretizável a deflagrar um debate acerca de sua efetiva solução em países como Argentina, Brasil e Colômbia.

A premissa básica seria o desenvolvimento de um diálogo inclusivo ${ }^{38}$, implicando a justificação das decisões tomadas pela participação, em processos de discussão, de todas as partes potencialmente afetadas, tomadas em posição de igualdade. O pressuposto para tanto é o de que o sistema de tomada de decisões dilui parcialidades a partir de uma discussão inclusiva de base ampla, permitindo que sejam ouvidos e considerados todos aqueles que dissentem. Alcançando maior abertura do debate, viabilizar-se-ia um ganho civilizatório e educativo, sustenta o autor, sobretudo quando se aceita que a ideia a prevalecer deve ser aquela que apresenta os melhores argumentos.

Nesse sentido, se enfrentaria uma das barreiras marcantes da atualidade, qual seja: o déficit de legitimidade democrática da jurisdição constitucional, tomada em sua forma forte, tal como apontado por Waldron ${ }^{39}$, o que impõe a dificuldade de reconhecimento da legitimidade das decisões das cortes constitucionais, uma vez que a estas cabe justificar as decisões judiciais não apenas para aqueles que a apoiam, mas, e especialmente, em face de seus opositores. Um tal estado de coisas, adverte Waldron, tende, em não sendo considerado, a conduzir a críticas dos atores políticos que tentam explorar uma fragilidade democrática acerca de supostos juízes ou mesmo quanto à irresponsabilidade política destes, pois não se submeteriam ao processo eleitoral como forma de prestação de contas para renovarem o seu cargo.

Ainda para Waldron ${ }^{40}$, parece surgir uma dificuldade contramajoritária operacional, findando por suplantar, sem a devida legitimidade eleitoral, as decisões políticas obtidas pela complexidade dos processos políticos (próprios de democracias maduras), conducentes a negociações e ajustes capazes de não deixar de lado qualquer interesse substancial da comunidade, mesmo quando se tratam de interesses mais frágeis ou sub-representados. Com isso, afirma, se daria um desrespeito a milhões de indivíduos (não grupos ou coletividades, mas pessoas singulares), os quais seriam privados de seus direitos políticos por um sistema forte de controle de constitucionalidade. Desta forma, violar-se-ia a igualdade democrática, a qual deixaria de servir como elemento de legitimidade política.

38 GARGARELLA, Roberto. El nuevo constitucionalismo dialógico frente ao sistema de lós frenos y contrapesos. In: GARGARELLA, Roberto (Comp.). Por uma justicia dialógica: el Poder Judicial como promotor de la deliberación democrática. Buenos Aires: Siglo Veintiuno Editores, 2014. p. 119-158. p. 124.

39 WALDRON, Jeremy. Control de Constitucionalidad y Legitimidad Política. Dikaion, v. 27, n. 1, p. 7-28, 2018. p. 17-19.

40 WALDRON, Jeremy. Control de Constitucionalidad y Legitimidad Política. Dikaion, v. 27, n. 1, p. 7-28, 2018. p. 19-22. 
Restaria, portanto, buscar formas de mitigação dessa dificuldade democrática, dentro dos contornos do que Gargarella ${ }^{41}$ chamou de "conversación extendida y entre iguales", como meio de superação da relação conflitiva equacionada nos modelos de funções estatais do século XVIII. Decerto, como apontado por Gargarella, se há dificuldades democráticas na jurisdição constitucional, por outro lado não se pode deixar de perceber que as decisões majoritárias ocasionais não podem ser tomadas como dados imodificáveis, senão como resultados endógenos de um processo no qual intervêm, muitas vezes, preconceitos, resignações, injustiças e desigualdades imotivadas de acesso à participação.

Nessa linha, convergem os autores, seria necessária a introdução de uma relação mais matizada entre os poderes judicial e legislativo, notadamente com o estabelecimento de um maior diálogo entre os tribunais e o Congresso, de forma genuinamente bilateral, como aponta Waldron ${ }^{42}$, lembrando, a pretexto de exemplificação de como isso ocorreria, algo muito próximo ao rito existente para a participação dos órgãos responsáveis pela edição da norma no controle de constitucionalidade concentrado, tal como se verifica no rito brasileiro. Entretanto, para ele, a Corte Constitucional não deveria ter a possibilidade de suplantar uma leitura alternativa das normas constitucionais por uma simples maioria, devendo, como forma de respeito ao processo democrático, exigir o que designa como "enfoque supermayoritario" (maioria qualificada, ou, mesmo, unanimidade) para a prevalência da postura dos magistrados quando em dissonância com o legislativo ${ }^{43}$.

De todo modo, para Waldron ${ }^{44}$, o principal objetivo de um processo decisório-dialógico deve ser o fortalecimento da legitimidade democrática pelo cuidado de se evitar a demonização do outro, dado que a legitimidade política não se trata, apenas, de uma relação entre indivíduo e governo, mas, para além disso, das múltiplas relações dos indivíduos entre si. Assim, a retórica do controle de constitucionalidade, a se fazer um canal de combate, denúncia e reprovação política do derrotado, não viabilizaria a percepção de transitoriedade que a vida na arena política oferece, especialmente quanto à reversão de insucessos passados, pelo que mostra, a legitimidade política ordinária, seus traços básicos de tolerância e civilidade, de modo a viabilizar a coexistência entre vencedores e vencidos no dia seguinte à decisão, afastando radicalismos de toda sorte.

\footnotetext{
41 GARGARELLA, Roberto. El nuevo constitucionalismo dialógico frente ao sistema de lós frenos y contrapesos. In: GARGARELLA, Roberto (Comp.). Por uma justicia dialógica: el Poder Judicial como promotor de la deliberación democrática. Buenos Aires: Siglo Veintiuno Editores, 2014. p. 119-158. p. 125.

42 WALDRON, Jeremy. Control de Constitucionalidad y Legitimidad Política. Dikaion, v. 27, n. 1, p. 7-28, 2018. p. 23.

43 WALDRON, Jeremy. Control de Constitucionalidad y Legitimidad Política. Dikaion, v. 27, n. 1, p. 7-28, 2018. p. 24.

44 WALDRON, Jeremy. Control de Constitucionalidad y Legitimidad Política. Dikaion, v. 27, n. 1, p. 7-28, 2018. p. 26-28.
} 
Gargarella ${ }^{45}$ observa, então, que o sistema de freios e contrapesos, em qualquer de suas variações, parece não ser capaz de canalizar um diálogo centrado no peso dos argumentos, mas, antes, na formação de negociações, por vezes instáveis e fragilizadas. Por isso, mostrar-se-ia inevitável a adoção de novos mecanismos dialógicos com a promoção de um papel de maior protagonismo para os órgãos políticos e maiores espaços para a consulta aos próprios afetados pelas decisões.

Percebe-se, contudo, a resistência de velhas estruturas institucionais (e, por vezes, discriminatórias) cristalizadas na dinâmica tradicional de freios e contrapesos, como aponta o autor, a destacar que tais práticas e experiências dialógicas findaram por serem abortadas quase antes de começarem, como se fizera sentir na Colômbia na atuação do estado de coisas inconstitucional em matéria de reorganização carcerária, com a prevalência de um ativismo expansivo, como visto acima ${ }^{46}$. Tal realidade finda por estabelecer um diálogo de elites, frustrando os ideais igualitários de uma democracia deliberativa, afastando o povo, com suas carências e aspirações, de uma efetiva participação política, restando apenas o uso limitado de debates públicos no interesse discricionário (ou arbitrário) das autoridades de turno ${ }^{47}$.

Diante de um tal marco teórico, mostra-se que a demanda por um constitucionalismo dialógico não parece se adequar à leitura tradicional do sistema de freios e contrapesos, implicando, ademais, a releitura de um sistema forte de controle de constitucionalidade. Assim, Mark Tushnet ${ }^{48}$ vem propor a dinâmica de um sistema fraco de controle de constitucionalidade como meio de efetivação dessa demanda dialógica, por ele chamada de revisão judicial dialógica.

Assim, tomando o mesmo ponto de partida fático presente em outros autores, ${ }^{49}$ Tushnet $^{50}$ ao analisar o advento da Carta Canadense de Direitos e Liberdades, de 1982,

45 GARGARELLA, Roberto. El nuevo constitucionalismo dialógico frente ao sistema de lós frenos y contrapesos. In: GARGARELLA, Roberto (Comp.). Por uma justicia dialógica: el Poder Judicial como promotor de la deliberación democrática. Buenos Aires: Siglo Veintiuno Editores, 2014. p. 119-158. p. 139-140.

46 GARGARELLA, Roberto. El nuevo constitucionalismo dialógico frente ao sistema de lós frenos y contrapesos. In: GARGARELLA, Roberto (Comp.). Por uma justicia dialógica: el Poder Judicial como promotor de la deliberación democrática. Buenos Aires: Siglo Veintiuno Editores, 2014. p. 119-158. p. 145-146 e 148-149.

47 GARGARELLA, Roberto. El nuevo constitucionalismo dialógico frente ao sistema de lós frenos y contrapesos. In: GARGARELLA, Roberto (Comp.). Por uma justicia dialógica: el Poder Judicial como promotor de la deliberación democrática. Buenos Aires: Siglo Veintiuno Editores, 2014. p. 119-158. p. 150-151.

48 TUSHNET, Mark. Revisión judicial dialógica. In: GARGARELLA, Roberto (Comp.). Por uma justicia dialógica: el Poder Judicial como promotor de la deliberación democrática. Buenos Aires: Siglo Veintiuno Editores, 2014, p. 105-116. p. 105.

49 GARGARELLA, Roberto. El nuevo constitucionalismo dialógico frente ao sistema de lós frenos y contrapesos. In: GARGARELLA, Roberto (Comp.). Por uma justicia dialógica: el Poder Judicial como promotor de la deliberación democrática. Buenos Aires: Siglo Veintiuno Editores, 2014. p. 119-158. p. 119; WALDRON, Jeremy. Control de Constitucionalidad y Legitimidad Política. Dikaion, v. 27, n. 1, p. 7-28, 2018. p. 12-13.

50 TUSHNET, Mark. Revisión judicial dialógica. In: GARGARELLA, Roberto (Comp.). Por uma justicia dialógica: el Poder Judicial como promotor de la deliberación democrática. Buenos Aires: Siglo Veintiuno Editores, 2014, p. 105-116. p. 105-106. 
observa que a revisão judicial dialógica se sustenta a partir de duas disposições centrais: uma de cunho substancial e outra de cunho procedimental. A disposição substancial consiste em "una cláusula de limitación general aplicable a todos los derechos constitucionales" por meio da qual tais direitos estão sujeitos a restrições impostas pela lei, justificando-se tal restrição "en nombre de una sociedad libre e democrática". A disposição procedimental, por sua vez, tem sido chamada de notwithstanding clause ou overriding clause, constante da seção 33 da referida Carta. Em suma, tal cláusula autoriza a legislatura (nacional ou provincial) a fazer sua legislação efetiva por um período de cinco anos, apesar de se possuir a desconfiança (ou mesmo a certeza) de que possa ser considerada por alguns (inclusive tribunais) como incompatível com vários direitos contidos na Carta.

A revisão judicial dialógica coloca em primeiro plano a inevitável tensão existente dentro do constitucionalismo democrático: o conflito entre seus compromissos de autogoverno popular (e prevalência da igualdade democrática como fonte de legitimação) e o estabelecimento de limites sobre as maiorias populares ${ }^{51}$.

Como forma de equacionamento desse desafio, o autor anteriormente referido propõe a revisão judicial dialógica, a qual traz como ideia básica fomentar diálogos entre as distintas funções estatais acerca de qual das interpretações concorrentes sobre as disposições constitucionais se apresentaria mais ajustada ao caso debatido. A vantagem desse proceder se mostra pela capacidade institucional das Cortes para centralizar as atenções sobre valores constitucionais que se ligam a problemas específicos, o que, no âmbito legislativo, terminaria sendo posto em risco pela perda de foco nos debates. Contudo, uma vez firmado o foco, se deveria deixar o valor do governo democrático seguir o seu curso, permitindo-se à legislatura a tomada de decisão final ${ }^{52}$.

Firmadas as noções sobre o constitucionalismo dialógico e a revisão judicial dialógica, cumpre observar se os institutos do compromisso significativo, como proposto, e do estado de coisas inconstitucional, como adotado no Brasil, servem para tanto.

\subsection{O compromisso significativo Sul-Africano e a proposta de sua recepção no Brasil: uma convergência ante o estado de coisas in- constitucional brasileiro?}

O compromisso significativo (meaningful engagement) surge na experiência sul-africana a partir de decisões da Corte Constitucional da África do Sul, notadamente

\footnotetext{
51 TUSHNET, Mark. Revisión judicial dialógica. In: GARGARELLA, Roberto (Comp.). Por uma justicia dialógica: el Poder Judicial como promotor de la deliberación democrática. Buenos Aires: Siglo Veintiuno Editores, 2014, p. 105-116. p. 106.

52 TUSHNET, Mark. Revisión judicial dialógica. In: GARGARELLA, Roberto (Comp.). Por uma justicia dialógica: el Poder Judicial como promotor de la deliberación democrática. Buenos Aires: Siglo Veintiuno Editores, 2014, p. 105-116. p. 112.
} 
acerca da necessidade de concretização do direito à moradia, em aporte construído ao longo de uma década. Iniciando-se com o caso Grootboom (2000) e avançando sobre o caso Olivia Road (2008), chegou-se à ideia de compromisso significativo, a qual foi refinada no caso Joe Slovo (2009)..$^{53}$

Cuidando do caso Olivia Road, a Corte foi confrontada com a situação de mais de 400 ocupantes de prédios em Johanesburgo, os quais se opuseram à ordem de desocupação apresentada pelo município junto à Suprema Corte de Apelações, sob a alegação de riscos à saúde e à segurança. Analisando o caso, a Corte Constitucional emitiu uma ordem provisória para o município e aos ocupantes para que se comprometessem significativamente a: (i) resolver suas diferenças e dificuldades à luz dos valores da Constituição; (ii) aliviar a condição dos que viviam nos edifícios, tornando-os seguros e saudáveis (seja pela realocação em acomodações definitivas ou temporárias); e, (iii) reportar os resultados do compromisso à Corte. ${ }^{54}$

Dessas experiências surgiu o entendimento acerca dos caracteres e pressupostos centrais para o compromisso significativo, apontando para um processo no qual, de forma prévia à formação de políticas públicas, estratégias ou desenvolvimento de projetos, busca-se a elaboração de um processo dialógico que se faça: (i) adequadamente estruturado, consistente e transparente, de modo a se evitar expectativas indevidas; (ii) leve em consideração as preferências linguísticas de cada população; e, (iii) viabilize a consideração e tratamento de indivíduos e comunidades como parceiros no processo de tomada de decisão $0^{55}$. Com base nesses pressupostos, como registram os mesmos autores, uma ampla principiologia foi desenvolvida a partir da casuística enfrentada com a busca de efetivação de direitos sociais na África do Sul, especialmente no que tange à moradia, sempre no intuito de viabilizar a superação de conflitos pela participação dos envolvidos e da percepção de seus respectivos pontos de vista, permitindo o consenso ${ }^{56}$.

\footnotetext{
53 VIEIRA JUNIOR, Ronaldo Jorge Araújo. Separação de poderes, estado de coisas inconstitucional e compromisso significativo: novas balizas à atuação do Supremo Tribunal Federal. Brasília: Núcleo de Estudos e Pesquisas/CONLEG/Senado, 2015. (Texto para discussão n 186). Disponível em: https://www12.senado.leg.br/ publicacoes/estudos-legislativos/tipos-de-estudos/textos-para-discussao/td186. Acesso em: 03 jun. 2019. p. 29; CHENWI, Lilia; TISSINGTON, Kate. Engaging meaninfully with government on socio-economic rights: a focus on the right to housing. University of the Western Cape: Community Law Centre, 2010. p. 4 e 24-27.

54 VIEIRA JUNIOR, Ronaldo Jorge Araújo. Separação de poderes, estado de coisas inconstitucional e compromisso significativo: novas balizas à atuação do Supremo Tribunal Federal. Brasília: Núcleo de Estudos e Pesquisas/CONLEG/Senado, 2015. (Texto para discussão n 186). Disponível em: https://www12.senado.leg.br/ publicacoes/estudos-legislativos/tipos-de-estudos/textos-para-discussao/td186. Acesso em: 03 jun. 2019. p. 29; CHENWI, Lilia; TISSINGTON, Kate. Engaging meaninfully with government on socio-economic rights: a focus on the right to housing. University of the Western Cape: Community Law Centre, 2010. p. 4 e 24-25.

55 CHENWI, Lilia; TISSINGTON, Kate. Engaging meaninfully with government on socio-economic rights: a focus on the right to housing. University of the Western Cape: Community Law Centre, 2010. p. 9 e 21.

56 CHENWI, Lilia; TISSINGTON, Kate. Engaging meaninfully with government on socio-economic rights: a focus on the right to housing. University of the Western Cape: Community Law Centre, 2010. p. 21-23.
} 
Assinala Pardo $^{57}$ que o diferencial dessa forma de trabalho é o alcance de resultados efetivos na formação e na concretização de políticas públicas a partir de uma solução pactuada, participativa e sob a fiscalização do Poder Judiciário, antes mesmo que se faça necessária a decisão jurisdicional. Assim, ter-se-ia a superação do binômio extremo de imunidade total da administração pública ou prevalência da absoluta sindicabilidade judicial, com a atuação do Judiciário como "indutor da deliberação política democrática", participando de "um jogo interativo, mais rico e complexo".

Como se pode ver dos posicionamentos analisados, há uma convergência no sentido da necessidade de se superar o relacionamento beligerante entre os poderes no sentido da criação de instrumentos sintetizadores de uma nova forma de cooperação, de modo a fazer sobressair sua atuação interdependente. A figura do compromisso significativo, apesar de não se encontrar expressamente prevista na Constituição Sul-Africana, delineia campo promissor a partir das decisões da Corte Constitucional daquele país, a qual se utilizou de fundamentos constitucionais diversos para construir o recorte inicial do instituto a ser utilizado ${ }^{58}$. Essa mesma realidade normativa é encontrada na Constituição Brasileira de 1988, pelo que tanto Pardo ${ }^{59}$, como Vieira Junior ${ }^{60}$ apontam sua compatibilidade com os fundamentos constitucionais brasileiros. Nesse sentido, tramitou, até o fim da última legislatura, o Projeto de Lei do Senado no 736/2015, de autoria do Senador Antônio Carlos Valadares (PSB/SE), o qual pretendia disciplinar o reconhecimento do estado de coisas inconstitucional e o uso do compromisso significativo no controle de constitucionalidade brasileiro como forma de se enfrentar os conflitos estruturais, mediante alterações na lei da ADPF.

Apesar de já se haver visto suficientemente a envergadura da técnica do estado de coisas inconstitucional na experiência colombiana, assim como sua relativamente tímida utilização na jurisdição constitucional brasileira, deve-se observar que, da forma como trabalhado no Brasil, o estado de coisas inconstitucional parece abrir, de fato, espaço para a convergência postulada pelo constitucionalismo dialógico, com o desafio de se implementarem, adequadamente, os pressupostos tanto do estado de coisas

57 PARDO, David Wilson de Abreu. Judiciário e políticas públicas ambientais: uma proposta de atuação baseada no "compromisso significativo". Revista de Direito Ambiental, São Paulo, v. 72, p. 161-210, out./dez. 2013. p. 186-187.

58 CHENWI, Lilia; TISSINGTON, Kate. Engaging meaninfully with government on socio-economic rights: a focus on the right to housing. University of the Western Cape: Community Law Centre, 2010. p. 11-12.

59 PARDO, David Wilson de Abreu. Judiciário e políticas públicas ambientais: uma proposta de atuação baseada no "compromisso significativo". Revista de Direito Ambiental, São Paulo, v. 72, p. 161-210, out./dez. 2013. p. 182.

60 VIEIRA JUNIOR, Ronaldo Jorge Araújo. Separação de poderes, estado de coisas inconstitucional e compromisso significativo: novas balizas à atuação do Supremo Tribunal Federal. Brasília: Núcleo de Estudos e Pesquisas/CONLEG/Senado, 2015. (Texto para discussão n 186). Disponível em: https://www12.senado.leg. br/publicacoes/estudos-legislativos/tipos-de-estudos/textos-para-discussao/td186. Acesso em: 03 jun. 2019. p. 32. 
inconstitucional, como do compromisso significativo (caso seja, efetivamente, do interesse coletivo a combinação das duas técnicas), com especial atenção para o fato de que não se mostraria viável uma simples transposição de institutos e parâmetros, como o da revisão judicial dialógica, dadas as deficiências próprias de países emergentes, como advertido por Gargarella ${ }^{61}$.

Com a definição do conflito estrutural acerca do sistema carcerário brasileiro como foco de considerações e cuidados do Supremo Tribunal Federal, o desafio presente para o desenvolvimento e para a concretização da ADPF n³47, ora em trâmite junto ao STF, será definir o grau de discricionariedade a ser oportunizado aos poderes Executivo e Legislativo para a superação desse estado de coisas inconstitucional, além de se estabelecer se haverá e como se daria o necessário acompanhamento da decisão, bem como os termos do diálogo institucional a ser oportunizado, o que findaria por abrir oportunidades para a experiência desse diálogo na forma do compromisso significativo entre poderes.

Resta saber, todavia, se as instâncias de poder estarão dispostas a desenvolver o diálogo proposto e quais as alternativas possíveis à Suprema Corte brasileira (e aos milhares de encarcerados) se a resposta for negativa, para que não restem violados os direitos fundamentais.

\section{CONCLUSÕES}

Diante do exposto, cumpre observar que a Corte Constitucional Colombiana, instada a se manifestar em casos de relevo e que caracterizavam verdadeiras demandas estruturais, delineou os contornos básicos e definiu os pressupostos do estado de coisas inconstitucional. Referida técnica decisória, uma vez adotada em oportunidades diversas, proporcionou à Corte experiência e acúmulo de aprendizagem naquilo que se refere à tutela dos direitos fundamentais em sua acepção objetiva.

Observa-se, contudo, que com a referida técnica decisória, a Corte Constitucional Colombiana inaugura uma forma de atuação que lhe autoriza a se imiscuir em questões das instâncias eletivas de poder para, por fim, revelar uma clara interferência em espaços de decisão próprios do Executivo e do Legislativo, especialmente no tocante à necessidade de elaboração e efetivação de políticas públicas, o que revela uma nítida postura ativista, passando a protagonizar papéis políticos, definindo e redefinindo prioridades orçamentárias, agendas políticas e supervisionando e/ou direcionando a atuação das demais esferas de poder.

61 GARGARELLA, Roberto. El nuevo constitucionalismo dialógico frente ao sistema de lós frenos y contrapesos. In: GARGARELLA, Roberto (Comp.). Por uma justicia dialógica: el Poder Judicial como promotor de la deliberación democrática. Buenos Aires: Siglo Veintiuno Editores, 2014. p. 119-158. p. 150-151. 
A Corte passou a se reconhecer como um dos principais instrumentos de transformação social, avançando, assim, sobre a função das demais instâncias de poder, o que viria a ensejar críticas de ordem democrática e de violação à teoria da separação de poderes. Ressalta-se, no entanto, que diante de uma paralisação das instâncias eletivas de poder, não poderia a Corte Constitucional Colombiana assumir outra postura, senão a de intervir em prol da tutela dos direitos fundamentais - observe-se que a atuação da Corte na definição da problemática e na apresentação de soluções é de suma relevância na determinação do êxito da decisão (veja-se, por exemplo, o caso da T-153, de 1988, e da ST-025, de 2004).

A recepção do estado de coisa inconstitucional no Brasil deu-se através da ADPF $347 / 2015$, oportunidade em que o STF foi instado a se manifestar acerca das condições estruturais do sistema penitenciário pátrio. No caso, percebe-se uma acanhada atuação da referida Corte, tendo-se limitado a emitir decisões cujos destinatários são os poderes Judiciário e Executivo, conforme já demonstrado, esquivando-se de adentrar em discussões relativas a políticas públicas capazes de solver, ou mesmo, amenizar a caótica situação que circunda o sistema prisional brasileiro, não se verificando, portanto, ofensas ao princípio democrático e/ou à separação de poderes.

Ressalta-se, contudo, que tomada a experiência da Corte Constitucional Colombiana, perdeu o STF a oportunidade de avançar rumo a uma maior e mais efetiva tutela dos direitos fundamentais, na medida em que deixou de dialogar com as demais instâncias de poder no sentido de encontrar uma alternativa factível para a solução da presente problemática.

Assim, ainda que o estado de coisas inconstitucional se apresente como uma via capaz de conduzir a um equacionamento da crise do sistema penitenciário, há que se definir como se dará a articulação entre as instâncias de poder a fim de que a atuação do STF não viole a separação de poderes, o princípio democrático e, tampouco, caia em descrédito.

Neste cenário, a ideia de um constitucionalismo dialógico, que implica no estabelecimento de um diálogo entre iguais a ser travado entre os poderes estatais, apresenta-se enquanto mecanismo capaz de mitigar a dificuldade democrática vislumbrada em um sistema forte de jurisdição constitucional. Referida dificuldade, consistente no prevalecimento de decisões oriundas de órgãos que não se submeteram a um processo eleitoral, restaria superada a partir de um debate com considerações de todos os órgãos, devendo prevalecer o entendimento que melhor atendesse as necessidades da comunidade.

Observa-se, todavia, conforme acima exposto, que o constitucionalismo dialógico não se adéqua à leitura tradicional do sistema de freios e contrapesos, razão pela 
qual Tushnet ${ }^{62}$ propôs a dinâmica de um sistema fraco de controle de constitucionalidade como meio de efetivação dessa demanda dialógica, por ele chamada de revisão judicial dialógica, a qual traz como ideia básica fomentar diálogos entre as distintas funções estatais acerca de qual das interpretações concorrentes sobre as disposições constitucionais se apresentaria mais ajustada ao caso debatido.

Nesse horizonte, observa-se, pois, que da forma como trabalhado no Brasil, o estado de coisas inconstitucional parece abrir, de fato, espaço para a convergência postulada pelo constitucionalismo dialógico, com o desafio de se implementarem, adequadamente, os pressupostos tanto do estado de coisas inconstitucional, como do compromisso significativo (caso seja, efetivamente, do interesse coletivo a combinação das duas técnicas), com especial atenção para o fato de que não se mostraria viável uma simples transposição de institutos e parâmetros, como o da revisão judicial dialógica, dadas as deficiências próprias de países emergentes com o risco da ocorrência de um diálogo de elites, como visto.

\section{REFERÊNCIAS}

AMORIM, Carlos. Comando Vermelho: a história do crime organizado. Rio de Janeiro: BestBolso, 2011.

ARIZA, Libardo José. Los derechos econômicos, sociales y culturales de las personas presas y la intervención de la Corte Constitucional en el sistema penitenciario colombiano. In: MALDONADO, Daniel Bonilla (Ed.). Constitucionalismo del Sur Global. Bogotá: Siglo del Hombre Editores, 2015. p. 169-204.

BRASIL. Constituição da República Federativa do Brasil de 1988. Disponível em: http://www. planalto.gov.br/ccivil_03/constituicao/ConstituicaoCompilado.htm. Acesso em: 25 maio 2019.

BRASIL. Lei 9.882, de 03 de dezembro de 1999. Dispõe sobre o processo e julgamento da argüição de descumprimento de preceito fundamental, nos termos do $\S 1^{\circ} \mathrm{do}$ art. 102 da Constituição Federal. Disponível em: http://www.planalto.gov.br/ccivil_03/leis/19882.htm. Acesso em: 25 maio 2019.

BRASIL. Senado Federal. Projeto de Lei do Senado, n 736, de 2015. Disponível em: https:// www25.senado.leg.br/web/atividade/materias/-/materia/124010. Acesso em: 25 maio 2019.

BRASIL. Supremo Tribunal Federal. ADPF 347. Disponível em: http://portal.stf.jus.br/processos/ detalhe.asp?incidente=4783560. Acesso em: 28 abr. 2018.

62 TUSHNET, Mark. Revisión judicial dialógica. In: GARGARELLA, Roberto (Comp.). Por uma justicia dialógica: el Poder Judicial como promotor de la deliberación democrática. Buenos Aires: Siglo Veintiuno Editores, 2014, p. 105-116. p. 105. 
BRASIL. Ministério da Justiça e Segurança Pública. Departamento Penitenciário Nacional - DEPEN. Levantamento Nacional de Informações Penitenciárias: Atualização - Junho 2016. Disponível em: https://tinyurl.com/ycg68vox. Acesso em: 28 abr. 2018.

BRASIL. Ministério da Justiça e Segurança Pública. Departamento Penitenciário Nacional - DEPEN. Agência Brasil. Com $\mathbf{7 2 6}$ mil presos, Brasil tem terceira maior população carcerária do mundo. Disponível em: https://tinyurl.com/y89ro2v2. Acesso em: 28 abr. 2018.

BRASIL. Conselho Nacional de Justiça. Disponível em: https://paineis.cnj.jus.br/QvAJAXZfc/opendoc.htm?document=qvw_l\%2FPainelCNJ.qvw\&host=QVS\%40neodimio03\&anonymous=true\&sheet=shBNMPIIMAPA. Acesso em: 12 set. 2019.

COLÔMBIA. Corte Constitucional de Colômbia. Sentencia T-025/2004. Disponível em: http:// www.corteconstitucional.gov.co/relatoria/2004/T-025-04.htm. Acesso em: 08 jun. 2019.

CASTORIADIS, Cornelius. A Instituição Imaginária da Sociedade. Trad. Guy Reynaud. Rio de Janeiro: Paz e Terra, 1982.

CHRISTINO, Marcio Sergio; TOGNOLLI, Claudio. Laços de Sangue: a história secreta do PCC. São Paulo: Matrix, 2017.

CAMPOS, Carlos Alexandre de Azevedo. Estado de Coisas Inconstitucional. Salvador: JusPodivm, 2016.

CHENWI, Lilia; TISSINGTON, Kate. Engaging meaninfully with government on socio-economic rights: A focus on the right to housing. University of the Western Cape: Community Law Centre, March, 2010.

DE GIORGI, Raffaele; VASCONCELOS, Diego de Paiva. Os fatos e as declarações: Reflexões sobre o estado de ilegalidade difusa. Revista Direito \& Praxis, Rio de Janeiro, v. 9, n. 1, p. 408-453, 2018. Disponível em: http://www.scielo.br/pdf/rdp/v9n1/2179-8966-rdp-9-1-480.pdf. Acesso em: 03 jun. 2019.

GARGARELLA, Roberto. El nuevo constitucionalismo dialógico frente ao sistema de lós frenos y contrapesos. In: GARGARELLA, Roberto (Comp.r). Por uma justicia dialógica: el Poder Judicial como promotor de la deliberación democrática. Buenos Aires: Siglo Veintiuno Editores, 2014. p. 119-158.

HERNÁNDEZ, Clara Inés Vargas. La garantía de la dimensión objetiva de los derechos fundamentales y labor del juez constitucional colombiano en sede de acción de tutela: el llamado "estado de cosas inconstitucional". Revista del Centro de Estudios Constitucionales, ano 1, n. 1, p. 203-228, 2003. Disponível em: https://www.redalyc.org/articulo.oa?id=82010111. Acesso em: 02 mar. 2019.

ITURRALDE, Manuel. Acceso a la justicia constitucional en Colombia: oportunidades y retos para la transformación social y política. In: MALDONADO, Daniel Bonilla (Ed.). Constitucionalismo del Sur Global. Bogotá: Siglo del Hombre Editores, 2015. p. 443-493. 
PARDO, David Wilson de Abreu. Judiciário e políticas públicas ambientais: uma proposta de atuação baseada no "compromisso significativo". Revista de Direito Ambiental, São Paulo, v. 72, p. 161-210, out./dez. 2013.

VIEIRA JUNIOR, Ronaldo Jorge Araújo. Separação de poderes, estado de coisas inconstitucional e compromisso significativo: novas balizas à atuação do Supremo Tribunal Federal. Brasília: Núcleo de Estudos e Pesquisas/CONLEG/Senado, 2015. (Texto para discussão n 186). Disponível em: https://www12.senado.leg.br/publicacoes/estudos-legislativos/tipos-de-estudos/textos-para-discussao/td186. Acesso em: 03 jun. 2019.

TUSHNET, Mark. Revisión judicial dialógica. In: GARGARELLA, Roberto (Comp.). Por uma justicia dialógica: el Poder Judicial como promotor de la deliberación democrática. Buenos Aires: Siglo Veintiuno Editores, 2014. p. 105-116.

WALDRON, Jeremy. Control de Constitucionalidad y Legitimidad Política. Dikaion, v. 27, n. 1, p. 7-28, 2018. 